\title{
Studies of heart block with His bundle electrograms
}

\author{
S. Bekheit ${ }^{1}$, J. G. Murtagh, P. Morton, and E. Fletcher \\ From the Cardiovascular Unit, Belfast City Hospital, Northern Ireland
}

A total of 24 patients with heart block revealed by scalar electrocardiography was studied using the His bundle electrogram. Four groups of disturbed conduction are described which include various types of heart block, partial and complete, at different sites, single and multiple, in the specialized conducting system. These are (I) intra-atrial block with delayed or blocked internodal conduction, (2) atrioventricular nodal block due to delayed or blocked conduction in the AV node, (3) His-Purkinje-system block due to delayed or blocked conduction in the fibres of the HisPurkinje-system, (4) multiple site AV block due to disturbances of conduction in the AV node and His-Purkinje-system in combination. His-Purkinje-system block is characterized by associated intraventricular block, and its relation to bilateral bundle-branch block and trifascicular block is discussed. In some instances concealed conduction disturbance, both anterograde and retrograde, is revealed by the His bundle electrogram, including facilitation of conduction in the main bundle of His. The His bundle electrogram defines more clearly the nature and extent of disturbed conduction and it may contribute to the choice of treatment, either by drugs or by artificial pacing, temporary or permanent.

The atrioventricular conduction tissues have two fundamental properties, the propagation of impulses and the formation of abnormal beats. Both properties are interdependent and influence each other. They have been extensively studied in animals using microelectrode techniques to measure transmembrane action potentials of myocardial fibres and of the specialized conducting tissues (Alanís, González, and López, 1958; Alanís et al., 1959; Hoffman et al., 1963). More recently, extracellular potentials generated by depolarization of the atrioventricular conduction tissues during the passage of impulses have been recorded in man by the technique described by Scherlag et al. (1969). Thus, disturbances of impulse formation and of impulse conduction can be studied more precisely under clinical conditions than has been possible hitherto. The method, which is simple in a properly equipped laboratory and is without undue risk or discomfort to the patient, has been employed in the study of atrioventricular block and the tachyarrhythmias and in measurements of normal sinus conduction (Damato et al., 1969; Narula et al., 1970b; Narula and

Received 2 December 197 I.

1 Research Fellow, Northern Ireland Hospitals' Authority.
Samet, 1970; Narula et al., I97 ; Castillo and Castellanos, 1970; Bekheit et al., 1971).

This paper is concerned with the study of abnormal conduction and impulse formation in the atria and junctional tissues. The use of the His bundle electrogram permits more precise location of the site of impulse delay than is possible with standard surface electrocardiograms, and the mechanisms involved can be shown more accurately. These factors are of great physiological importance and point to the need for revision of current concepts of interpretation of Wenckebach block (Mobitz I) and Mobitz II block, based on duration of refractoriness (Wenckebach, 1899, 1906; Mobitz, 1924). The His bundle electrogram shows that multiple sites of block of varying degrees can occur in the conduction system (Narula et al., 1970b) and, moreover, as we will show, it indicates that conduction disturbances concealed in standard leads may become revealed. There is necropsy evidence that Adams-Stokes attacks are particularly associated with isolated disease in the fibres of the His-Purkinje-system (Davies and Harris, 1969). The His bundle electrogram permits location of the site or sites of such disease, and thereby may have practical clinical application, for example when surface leads show trifascicular block (Rosenbaum, Elizari, and 
TABLE Classification of heart block

\begin{tabular}{|c|c|c|c|c|c|c|c|c|c|c|}
\hline \multirow[t]{2}{*}{ Type of heart block } & \multirow{2}{*}{$\begin{array}{l}\text { Case } \\
\text { No. }\end{array}$} & \multirow{2}{*}{$\begin{array}{l}\text { Sex } \\
\text { and } \\
\text { age }\end{array}$} & \multirow[t]{2}{*}{ Disease } & \multirow{2}{*}{$\begin{array}{l}\text { Syn- } \\
\text { cope }\end{array}$} & \multicolumn{3}{|c|}{ Standard electrocardiogram } & \multicolumn{3}{|c|}{ Bundle of His electrogram } \\
\hline & & & & & $\begin{array}{l}P R \\
(\text { msec) } \\
(\text { normal } \\
<200)\end{array}$ & $\begin{array}{l}\text { QRS } \\
(\text { msec) } \\
(\text { normal } \\
<\text { IOO) }\end{array}$ & $\underset{\text { axis }}{Q R S}$ & $\begin{array}{l}P A \\
\text { (msec) } \\
\text { (normal } \\
\text { IO-45) }\end{array}$ & $\begin{array}{l}\text { AH } \\
\text { (msec) } \\
\text { (normal } \\
50-125)\end{array}$ & $\begin{array}{l}\text { BH } \\
\text { (msec) } \\
\text { (normal } \\
\text { I5-25) }\end{array}$ \\
\hline \multicolumn{11}{|l|}{$\begin{array}{l}\text { GROUP I } \\
\text { Intra-atrial block (PA) } \\
\text { (A) }\end{array}$} \\
\hline Ist-degree & $\mathbf{I}$ & $\mathrm{F} 48$ & Sarcoidosis & - & $250-260$ & 70 & $+58^{\circ}$ & $70-85$ & $125-130$ & 20 \\
\hline \multicolumn{11}{|l|}{$\begin{array}{l}\text { GROUP II } \\
\text { AV nodal (AH) block } \\
\text { (A) }\end{array}$} \\
\hline \multirow[t]{4}{*}{ Ist-degree } & 2 & F 52 & $\begin{array}{l}\text { Idiopathic heart } \\
\text { block }\end{array}$ & + & $250-265$ & 80 & $+40^{\circ}$ & 40 & $170-180$ & 20 \\
\hline & 3 & F 64 & $\begin{array}{l}\text { Coronary heart } \\
\text { disease }\end{array}$ & + & $285-290$ & 80 & $+12^{\circ}$ & $30-40$ & $215-220$ & 20 \\
\hline & 4 & F 46 & $\begin{array}{l}\text { Idiopathic heart } \\
\text { block }\end{array}$ & + & $220-230$ & 70 & $+68^{\circ}$ & $20-30$ & $150-160$ & 15 \\
\hline & 5 & $M 58$ & $\begin{array}{l}\text { Coronary heart } \\
\text { disease }\end{array}$ & + & $330-340$ & 80 & $+90^{\circ}$ & $10-15$ & $275-280$ & I5 \\
\hline \multirow[t]{2}{*}{$\begin{array}{l}\text { With blocked beats } \\
\text { partial/complete }\end{array}$} & 6 & $M 52$ & $\begin{array}{l}\text { Idiopathic heart } \\
\text { block }\end{array}$ & - & $345-505$ & 80 & $+30^{\circ}$ & 35 & $270-430$ & 20 \\
\hline & 7 & F 80 & $\begin{array}{l}\text { Idiopathic heart } \\
\text { block }\end{array}$ & + & $225-230$ & 80 & $-30^{\circ}$ & 25 & $175-180$ & 20 \\
\hline \multirow{8}{*}{$\begin{array}{c}\text { GROUP III } \\
\text { His-Purkinje-system } \\
\text { (HV) block } \\
\text { (AI) } \\
\text { Ist-degree normal PR }\end{array}$} & & & & & & & & & & \\
\hline & 8 & M 69 & $\begin{array}{l}\text { Coronary heart } \\
\text { disease }\end{array}$ & + & $130-140$ & 120 & $+6 \mathrm{I}^{\circ}$ & 5 & $60-70$ & 20 \\
\hline & 9 & M 50 & Cardiomyopathy & - & $170-180$ & 70 & $-75^{\circ}$ & $20-30$ & $70-80$ & 15 \\
\hline & 10 & F 67 & $\begin{array}{l}\text { Coronary heart } \\
\text { disease }\end{array}$ & + & $190-200$ & I Io & $-28^{\circ}$ & $15-20$ & $110-120$ & 20 \\
\hline & II & M 63 & $\begin{array}{l}\text { Coronary heart } \\
\text { disease }\end{array}$ & + & $175-185$ & 140 & $-10^{\circ}$ & $35-40$ & $75-80$ & 15 \\
\hline & 12 & M 57 & $\begin{array}{l}\text { Coronary heart } \\
\text { disease }\end{array}$ & + & $190-195$ & 140 & $-15^{\circ}$ & $30-40$ & $80-90$ & 20 \\
\hline & 13 & M 54 & $\begin{array}{l}\text { Coronary heart } \\
\text { disease }\end{array}$ & - & $170-180$ & I IO & $+60^{\circ}$ & $20-30$ & $70-80$ & 25 \\
\hline & 14 & M 69 & $\begin{array}{l}\text { Coronary heart } \\
\text { disease }\end{array}$ & - & $190-200$ & 105 & $-34^{\circ}$ & $10-20$ & $100-110$ & 20 \\
\hline Ist-degree prolonged PR & 15 & $M 52$ & $\begin{array}{l}\text { Coronary heart } \\
\text { disease }\end{array}$ & - & $220-230$ & 170 & $-60^{\circ}$ & $30-40$ & $100-105$ & 20 \\
\hline \multirow[t]{2}{*}{$\begin{array}{l}\text { Blocked beats partial/ } \\
\text { complete }\end{array}$} & 16 & F 62 & $\begin{array}{l}\text { Idiopathic heart } \\
\text { block }\end{array}$ & + & $185-190$ & 160 & $-34^{\circ}$ & $25-35$ & $75-85$ & I5 \\
\hline & 17 & M 63 & $\begin{array}{l}\text { Idiopathic heart } \\
\text { block }\end{array}$ & + & $190-315$ & 160 & $-55^{\circ}$ & $25-30$ & $65-75$ & 15 \\
\hline \multirow[t]{7}{*}{$\begin{array}{l}\text { GROUP IV } \\
\text { Combined AV nodal }+ \\
\text { His Purkinje (AH }+ \\
\text { HV) block }\end{array}$} & 18 & F 67 & $\begin{array}{l}\text { Idiopathic heart } \\
\text { block }\end{array}$ & + & - & 120 & $+54^{\circ}$ & ro & $175-180$ & $45-65$ \\
\hline & 19 & M r9 & $\begin{array}{l}\text { Aortic and mitral } \\
\text { valve disease }\end{array}$ & - & $230-240$ & 90 & $S_{1} S_{2} S_{3}$ & $20-25$ & $140-150$ & 25 \\
\hline & 20 & M 69 & $\begin{array}{l}\text { Coronary heart } \\
\text { disease }\end{array}$ & - & $230-240$ & I 10 & $-50^{\circ}$ & $20-30$ & $130-140$ & 15 \\
\hline & $2 \mathrm{I}$ & M 66 & $\begin{array}{l}\text { Coronary heart } \\
\text { disease }\end{array}$ & + & $225-235$ & I IO & $-50^{\circ}$ & $25-35$ & $130-140$ & 15 \\
\hline & 22 & M 56 & $\begin{array}{l}\text { Coronary heart } \\
\text { disease }\end{array}$ & - & $250-260$ & 140 & $-40^{\circ}$ & $10-20$ & $170-180$ & I5 \\
\hline & 23 & M 54 & $\begin{array}{l}\text { Coronary heart } \\
\text { disease }\end{array}$ & - & $220-230$ & 80 & $S_{1} S_{2} S_{3}$ & $20-30$ & $140-145$ & I5 \\
\hline & 24 & $M 58$ & $\begin{array}{l}\text { Coronary heart } \\
\text { disease and } \\
\text { cor pulmonale }\end{array}$ & - & $215-225$ & 100 & $+138^{\circ}$ & $20-30$ & $135-145$ & 20 \\
\hline
\end{tabular}




\section{Remarks}

HV
(msec)
$\begin{aligned} & \text { (normal } \\ & \text { 35-45) }\end{aligned}$

Lazzari, 1970) or suggest bilateral bundlebranch block (Lenegre, 1964; Schuilenburg and Durrer, 1970). This study shows first, disturbances of conduction of sinus impulses due to block, single and multiple, partial and complete in the intra-atrial and junctional tissues, and second it is concerned with concealed conduction disturbances both anterograde and retrograde, all of which are revealed by the His bundle electrogram. Before presentation of our results the His bundle electrogram will be described briefly.

There is good evidence that the sinus impulse reaches the AV node by internodal preferential pathways (James, 1963) and enters the AV node from the right atrium (Scherf and Cohen, 1964). Thereafter the sinus impulse is normally delayed in some unknown way, probably the result of varying duration

FI G. I (Table, Case I.) First-degree block (Group $I, A)$. The PR interval is prolonged, 250-260 msec. Delayed conduction in the internodal fibres is the chief contributory factor, as the PA interval is conspicuously prolonged to $70-85 \mathrm{msec}$ (normal $\leq 45 \mathrm{msec}$ ). AV nodal and His-Purkinje-system conduction were just above upper limits for normal values for $A H$ interval (normal $\leq 125 \mathrm{msec}$ ), and HV intervals, 50-55 msec (normal 35-45 msec). Distance between two light vertical lines $40 \mathrm{msec}$. The standard leads showed no abnormality apart from first degree $A V$ block. Records from a woman aged 48 years with advanced sarcoidosis.

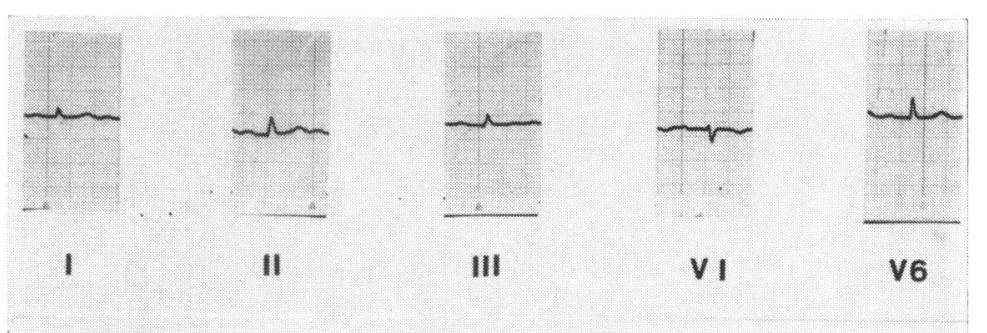
Mobitz II pacemaker Right bundle-branch block; left anterior hemiblock; 2: I and 3: I block

Complete heart block; $\mathrm{AH}$ Ist-degree; right bundlebranch block

AH Ist-degree; HV MPS Ist-degree

AH Ist-degree; HV Ist-degree; left anterior hemiblock

AH Ist-degree; HV Ist-degree; left anterior hemiblock

AH Ist-degree; HV rst-degree; left bundle-branch block

AH Ist-degree; HV 2: I block

$\begin{array}{ll}60 & - \\ 60 & +\end{array}$

AH Ist-degree; HV Ist-degree; right bundle-branch block 
of action potentials of the atrial fibres immediately adjacent to the AV node (Scherf and Cohen, 1964). Conduction in the AV node and the His-Purkinje-system is myogenic, though in the former it is influenced by the autonomic nervous system. The His bundle electrogram is recorded from an electrode catheter placed astride the atrioventricular conduction fibres. It is so called because of the prominent potential produced by the main bundle of His ( $\mathrm{BH}$ wave) either as a biphasic or triphasic deflection. The initial deflections (A wave) represent depolarization of atrial fibres immediately adjacent to the AV node, and the interval between the first rapid deflection of the $A$ wave and the beginning of the $\mathrm{BH}$ wave is a measurement of conduction time in the AV node (Hoffman et al., 1963). Depolarization of the AV node itself may be marked by a notched deflection ( $N$ wave) near the termination of the A wave (Damato et al., 1970), but in our tracings this could not be identified with certainty. The $\mathrm{BH}$ wave is followed by rapid deflections of initiation of ventricular depolarization ( $V$ wave) and the interval between the beginning of the $\mathrm{BH}$ wave and the first rapid deflection of the $\mathrm{V}$ wave represents conduction time through the main bundle of His to the Purkinje myocardial junction. If the electrode catheter is advanced too far into the right ventricle depolarization of the right bundle-branch may be recorded ( $\mathrm{RB}$ wave). It may simulate the $\mathrm{BH}$ wave but can be differentiated readily from it by pacing the atrium or main bundle of His (Narula, Scherlag, and Samet, 1970c). The nomenclature of the deflections of the His bundle electrogram has not been formalized as yet and the symbols employed in this paper are those used by the pioneer workers already mentioned. In summary, the His bundle electrogram measures AV node conduction (AH interval) and His-Purkinje-system conduction (HV interval) and when correlated

FIG. 2 (Table, Case 3.) First-degree AV nodal block (Group II, A). The PR interval in scalar lead is prolonged, 285-290 msec. The AH interval is abnormally prolonged to 21 5-220 msec (normal, $\leq 125 \mathrm{msec}$ ). Intra-atrial conduction, $P A$ interval, $30-40 \mathrm{msec}$, is normal ( $\leq 45 \mathrm{msec}$ ). His-Purkinje-system conduction is also normal, $H V$ interval 35 msec (normal, 35-45 msec). Delayed conduction occurred exclusively in the $A V$ node. Distance between two light vertical lines 40 msec. The standard leads showed low $T$ wave voltage with first-degree $A V$ block. Tracings recorded from a woman aged 64 years with coronary disease.

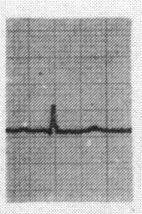

1

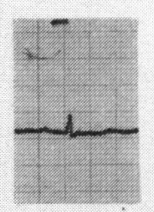

11

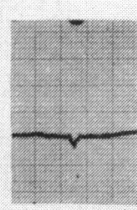

111

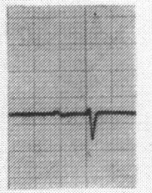

vi

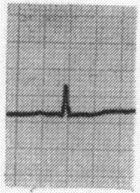

v6

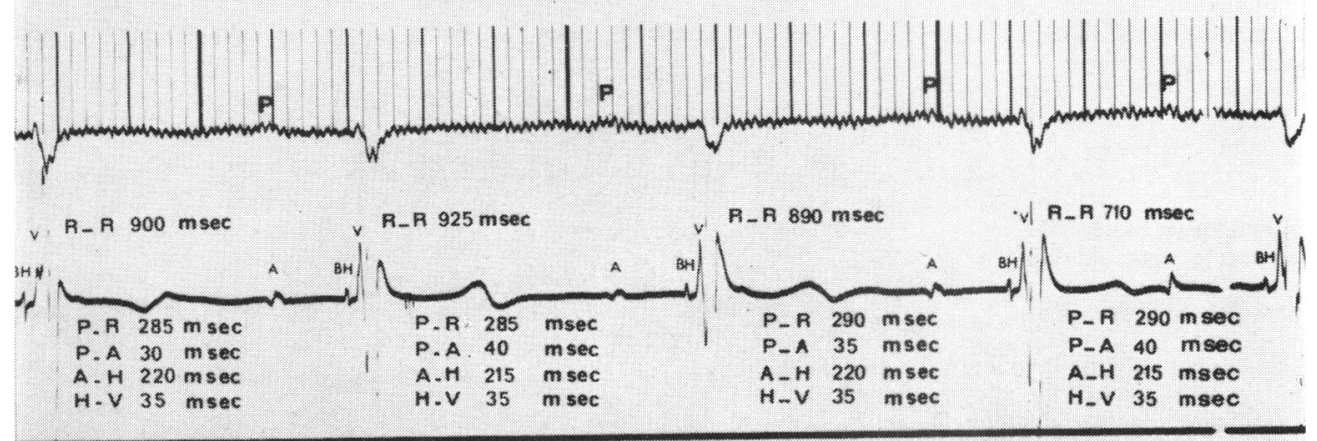


with a surface lead, the distance between the beginning of the $P$ wave of the standard electrocardiogram and the beginning of the $A$ wave of the His bundle electrogram (PA interval) is a measurement of internodal atrial conduction.

\section{Subjects and methods}

A total of 24 patients was studied, 17 men and 7 women (age range 19 to 80 years). All of them had organic heart disease. Coronary artery disease was present in 14 patients and rheumatic heart disease in one. Seven patients were considered to have isolated fibrosis of the specialized conducting tissues and the remaining 2 had congestive cardiomyopathy and advanced sarcoidosis, respectively. The standard electrocardiograms were abnormal in all of them, and in particular showed either atrioventricular block or intraventricular block, or both types of conduction disturbance. The clinical data, electrocardiographic findings, and the measurements determined from the His bundle electrograms are summarized in the Table.

The details of the method by which the His bundle electrograms were recorded have been described by us previously (Bekheit et al., 1971). Long strips of not less than one hundred cycles were recorded at a paper speed of $100 \mathrm{~mm} \mathrm{a}$ second from which the measurements were made. The normal values for the intervals PA (25-45 $\mathrm{msec}$ ), AH (50-125 msec), BH (I $-20 \mathrm{msec}$ ), and HV (35-45 msec) were used for controls in our measurements (Narula et al., I970a; Bekheit et al., 1971). Selected tracings are illustrated in Fig. I-I3.

\section{Results: classification of abnormal con- duction}

The His bundle electrograms record abnormal conduction under resting conditions without any form of intervention, and they illustrate various types of heart block, partial and complete, at different sites in the conducting system both single and multiple. For purposes of description the various types of block have been divided into four main groups according to the site of block. It is suggested, however, that such a classification may have practical clinical significance in addition to allowing a more precise understanding of the mechan-

- isms of abnormal conduction.

Group I: Intra-atrial block with delayed or blocked internodal conduction (Table, Case I) The conduction disturbance may represent abnormal delay in the preferential internodal pathways occurring simultaneously.

- The sinus impulse may be delayed causing a prolonged PA interval (type A) or it may be blocked (type B). An example of type A intraatrial block only is available in our series.
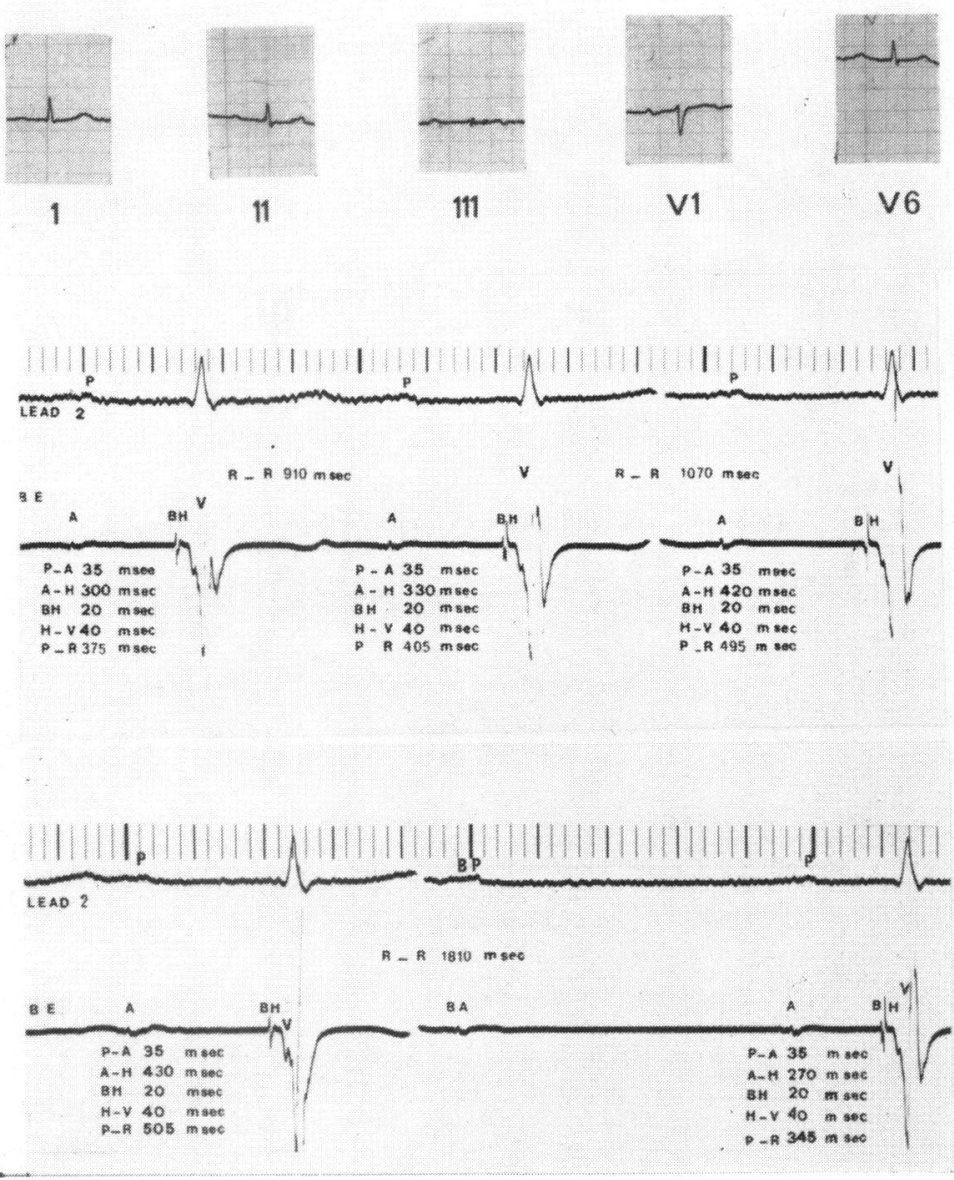

FIG. 3 (Table, Case 6.) AV nodal Wenckebach block (Group II, B). The bundle of His tracings are continuous. Note progressive prolongation of $A H$ interval from 270-430 msec. His-Purkinje-system conduction remains normal, $40 \mathrm{msec}$ (normal, 35-45 msec). The blocked beat $(B A)$ is not followed by a $B H$ wave, indicating that the site of impaired conduction and block is exclusive to the $A V$ node. Distance between two light vertical lines $40 \mathrm{msec}$. Standard leads were normal apart from $A V$ block. The tracings are from a man aged 52 years without definite cardiac symptoms.

First-degree intra-atrial block with delayed internodal conduction, Fig. I (Table, Case I) The tracing was recorded from a woman aged 48 years with advanced sarcoidosis. The surface electrocardiogram showed a prolonged PR interval (250-260 msec). The bundle of His electrogram revealed prolongation of the PA interval from 70-85 msec (normal 25-45 $\mathrm{msec}$ ) with normal conduction in the AV node 


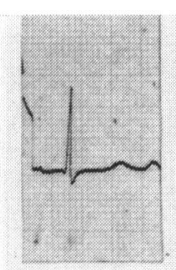

1

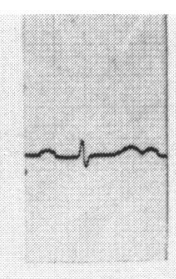

11

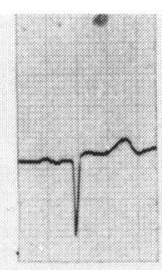

III

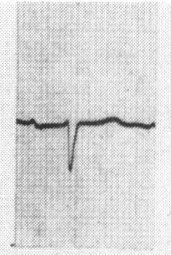

VI

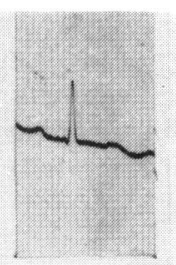

V6
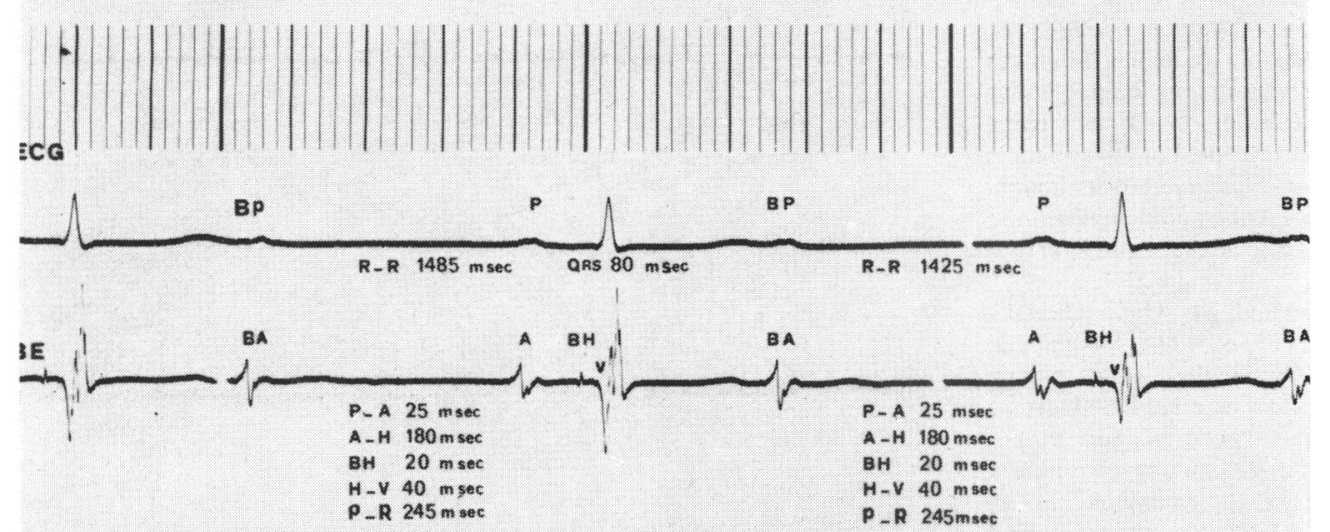

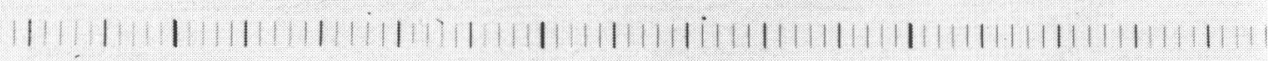

FIG. 4 (Table, Case 7.) 2:I AV nodal block (Group II, B). The PR interval of the conducted beats is prolonged to $245 \mathrm{msec}$. The His bundle electrogram confirms that the delayed conduction is exclusive to the $A V$ node, as the $A H$ interval is abnormally prolonged to 180 msec (normal $\leq 125 \mathrm{msec}$ ). The blocked beats (BA in His bundle electrogram) are not followed by a $B H$ wave. The impulse is therefore blocked in the AV node. His-Purkinje-system conduction is normal, $H V$ interval $40 \mathrm{msec}$ (normal, 35-45 $\mathrm{msec}$ ). Distance between two light vertical lines $40 \mathrm{msec}$. Tracings recorded from a woman aged 80 years.

(AH interval $125 \mathrm{msec}$ ) and a slightly prolonged $\mathrm{HV}$ interval, 50-55 $\mathrm{msec}$ (normal 35$45 \mathrm{msec}$ ). This is explained by delay in the conduction of the sinus impulse through the internodal fibres. The slight prolongation of the $\mathrm{HV}$ interval denotes, in addition, a delay in conduction in the main bundle of His.

Group II: Atrioventricular nodal block (Table, Cases 2-7) In atrioventricular nodal block the delayed or blocked conduction is confined to the AV node. The His bundle electrogram does not discriminate between abnormal conduction located at the atrionodal junction ( $\mathrm{N}$ region) and the junction of the distal end of the AV node with the main bundle of His. It is convenient to subdivide AV nodal block into two types, (A) first-degree AV nodal block, characterized by prolongation of the AH interval, and (B) AV nodal block with blocked impulses, partial or complete, in which the blocked impulses are not followed by a $\mathrm{BH}$ wave.

(A) First-degree $A V$ nodal block Four patients had conduction disturbances of this 
type (Table, Cases 2-5). All of them had a history of syncopal attacks, suggesting that partial or complete AV nodal block may have occurred intermittently. The characteristic features were ( $I$ ) prolonged PR interval in the surface leads greater than $200 \mathrm{msec}$ (range 220-340 msec); (2) prolonged AH interval greater than $120 \mathrm{msec}$ (range 155-280 msec); (3) normal BH, HV, and QRS intervals. The QRS axis of the surface electrocardiograms ranged from $+12^{\circ}$ to $+90^{\circ}$ consistent with normal conduction in the distal part of the His-Purkinje-system. The tracing (Fig. 2, Case 3) was recorded from a woman aged 64 years with syncopal attacks. The PR interval of the surface electrocardiogram was prolonged to $290 \mathrm{msec}$. The His bundle electrogram revealed that the $\mathrm{AH}$ interval was prolonged to $220 \mathrm{msec}$. The PA, BH, HV, and QRS intervals were normal. Thus, the His bundle electrogram showed that the prolonged PR interval was entirely due to delayed conduction in the AV node.

(B) Atrioventricular nodal block with blocked sinus impulses Two patients had conduction disturbances of this type (Table, Cases 6 and 7). When sinus beats were conducted the criteria for diagnosis were the same as in Group II (A), but when they were blocked the $\mathrm{A}$ waves were not followed by $\mathrm{BH}$ waves. This type of block includes varying degrees of partial heart block, including Wenckebach block (Mobitz I block). The essential facts are that the AV node is the site of block and conduction is intact in the His-Purkinje-system. An example of Wenckebach block, Fig. 3 (Table, Case 6) was recorded from a man aged 52 years. A long strip from lead II of the surface electrocardiogram showed a prolonged PR interval and episodes of Wenckebach block (Mobitz I block). The PR interval varied from 280-505 msec in the conducted sinus beats. The His bundle electrogram showed prolongation of the AH interval within the range $230-420 \mathrm{msec}$. The $\mathrm{HV}$ intervals of the conducted sinus beats were normal. Blocked sinus impulses were not followed by $\mathrm{BH}$ waves. The His bundle electrogram confirmed, therefore, that the Wenckebach block was located entirely in the AV node, and the His-Purkinje-system conduction was normal.

An example of 2:I AV nodal block (Fig. 4) was recorded from a woman aged 80 years (Case 7) who had a history of syncopal attacks over a period of two years. Surface electrocardiograms indicated varying degrees of $\mathrm{AV}$ block. The conducted sinus beats had a prolonged PR interval (225 msec). Fig. 4 shows a His bundle electrogram recorded during a
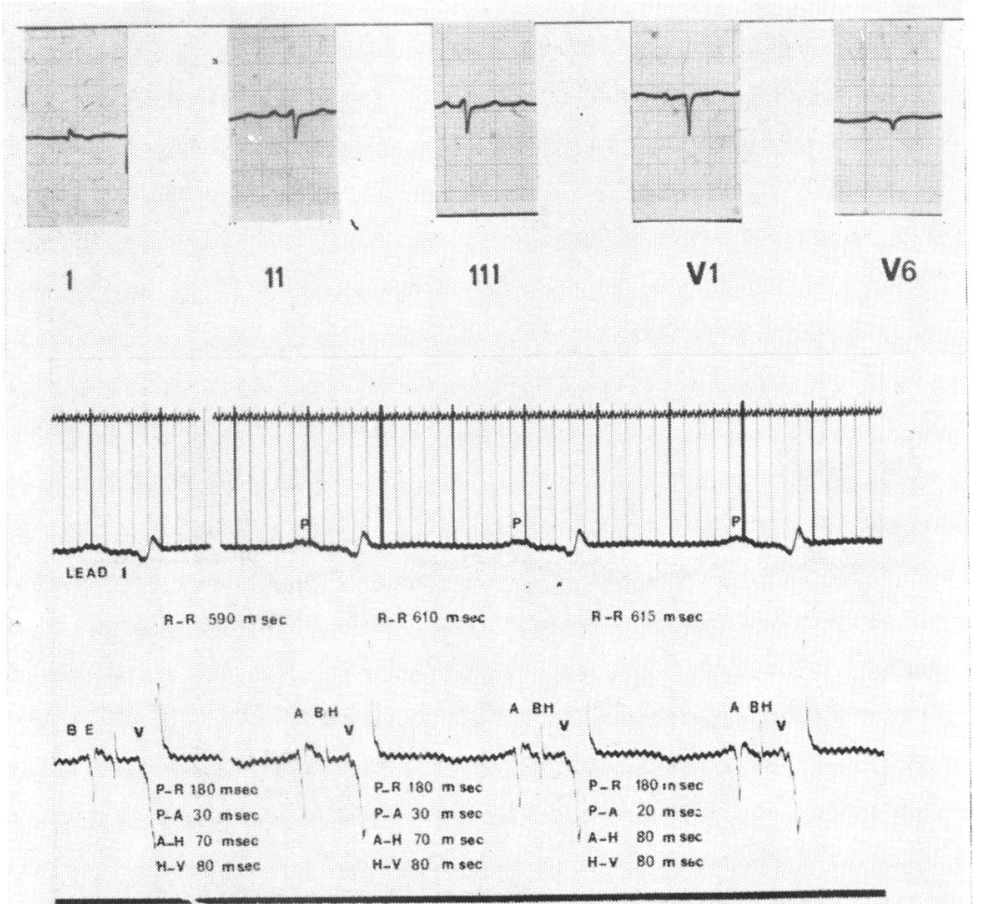

FIG. 5 (Table, Case 9.) First-degree HisPurkinje-system block with normal PR interval (Group III, AI). The PR interval measures 180 msec. Intra-atrial conduction and $A V$ nodal conduction are normal, $P A$ interval 30 msec, and $A H$ interval, 70-80 msec. The $H V$ interval is prolonged to 80 msec (normal 35-45 msec), confirming delayed conduction in His-Purkinje-system. Distance between two light vertical lines $40 \mathrm{msec}$. The standard leads show left anterior hemiblock ( -75 degrees). Tracings were recorded from a man aged 50 years with congestive cardiomyopathy.

static phase of 2: I AV block. The AH interval of the alternate conducted sinus beats was prolonged to 180 msec but their $\mathrm{HV}$ interval was normal. The $A$ waves of the blocked sinus impulses were not followed by $\mathrm{BH}$ waves. Thus, the delay and block in conduction was located in the AV node.

Group III: His-Purkinje-system block (Table, Cases 8-17) In His-Purkinje-system block the delay or blocked conduction is confined to the main bundle of His, or its bundle-branches and their ramifications. It is of topical interest in view of its relation to bilateral bundle-branch block as a common 

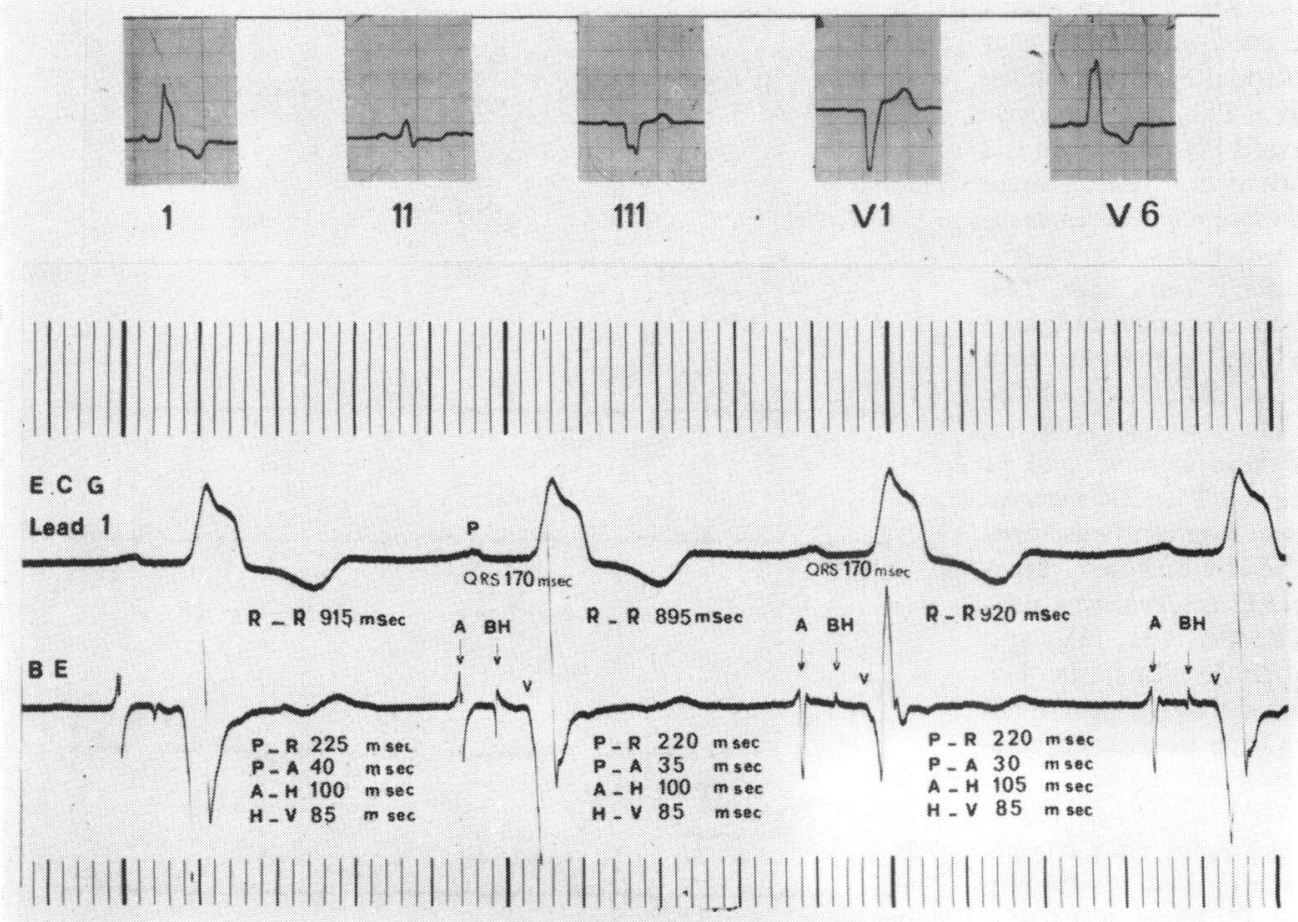

FIG. 6 (Table, Case I5.) First-degree His-Purkinje-system block with prolonged PR interval and complete left bundle-branch block (Group III, A2). The PR interval is prolonged to 220 msec. Intra-atrial and $A V$ nodal conduction are normal, the $P A$ interval, 30-40 msec (normal $\leq 45 \mathrm{msec}$ ), and AH interval, 100-105 msec (normal $\leq 125 \mathrm{msec}$ ). The prolonged HV interval, $85 \mathrm{msec}$ (normal, 35-45 $\mathrm{msec}$ ), confirms that there was delayed conduction in the His-Purkinje-system. Distance between two light vertical lines 40 msec. The standard leads also confirm abnormal conduction in the left bundle of His. The tracings were recorded from a man aged 52 years with coronary heart disease.

mechanism of complete heart block (Lenegre, 1964) and the significance of the hemiblocks as indicators of disease of the Purkinje fibres (Rosenbaum, Elizari, and Lazzari, 1968). Our cases had either right or left bundle-branch block with a prolonged QRS interval, or left anterior hemiblock when the QRS interval was normal. As in Group II, it is convenient to subdivide the His-Purkinje-system block into two types: (A) first-degree His-Purkinjesystem block characterized by prolongation of the $\mathrm{HV}$ interval, and (B) His-Purkinje-system block with blocked sinus impulses which includes various types of partial and complete heart block in which the blocked impulses are not followed by $\mathrm{V}$ waves.

(A) First-degree His-Purkinje-system block (Table, Cases 8-15) The characteristic features were (I) prolonged $\mathrm{HV}$ interval greater than 45 msec (range 65-90 msec), (2) normal PA and
AH intervals, and (3) intraventricular block either right or left bundle-branch block, left anterior hemiblock, or indeterminate intraventricular block. The implication of intraventricular block is that the disease process which delays His-Purkinje-system conduction extends proximally to involve the main bundle or the contralateral branch. However, if the His-Purkinje-system block is due to an isolated lesion of the main bundle of His, intraventricular conduction may be normal and the block may be revealed by changes in the duration of the BH wave which may be duplicated ( $\mathrm{BH}$ and $\mathrm{B} \overline{\mathrm{H}}$ waves, Narula et al., 1970a).

Before describing our tracings, some comments on the duration of the PR interval may be useful. The PR interval of conducted beats in the electrocardiogram comprises the PA, $\mathrm{AH}$, and $\mathrm{HV}$ intervals of the $\mathrm{His}$ bundle electrogram. Assuming minimal values of 25 $\mathrm{msec}$ for the PA interval and $50 \mathrm{msec}$ for the 


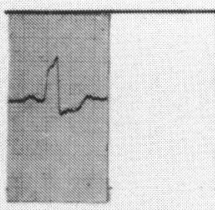

1

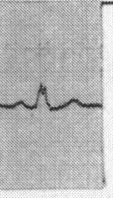

11

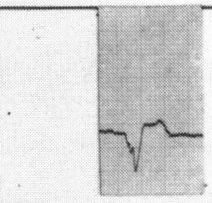

111

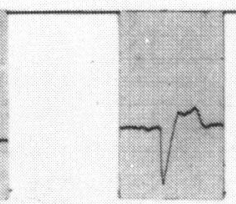

$\mathbf{V}_{1}$

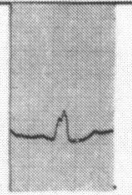

$V_{6}$
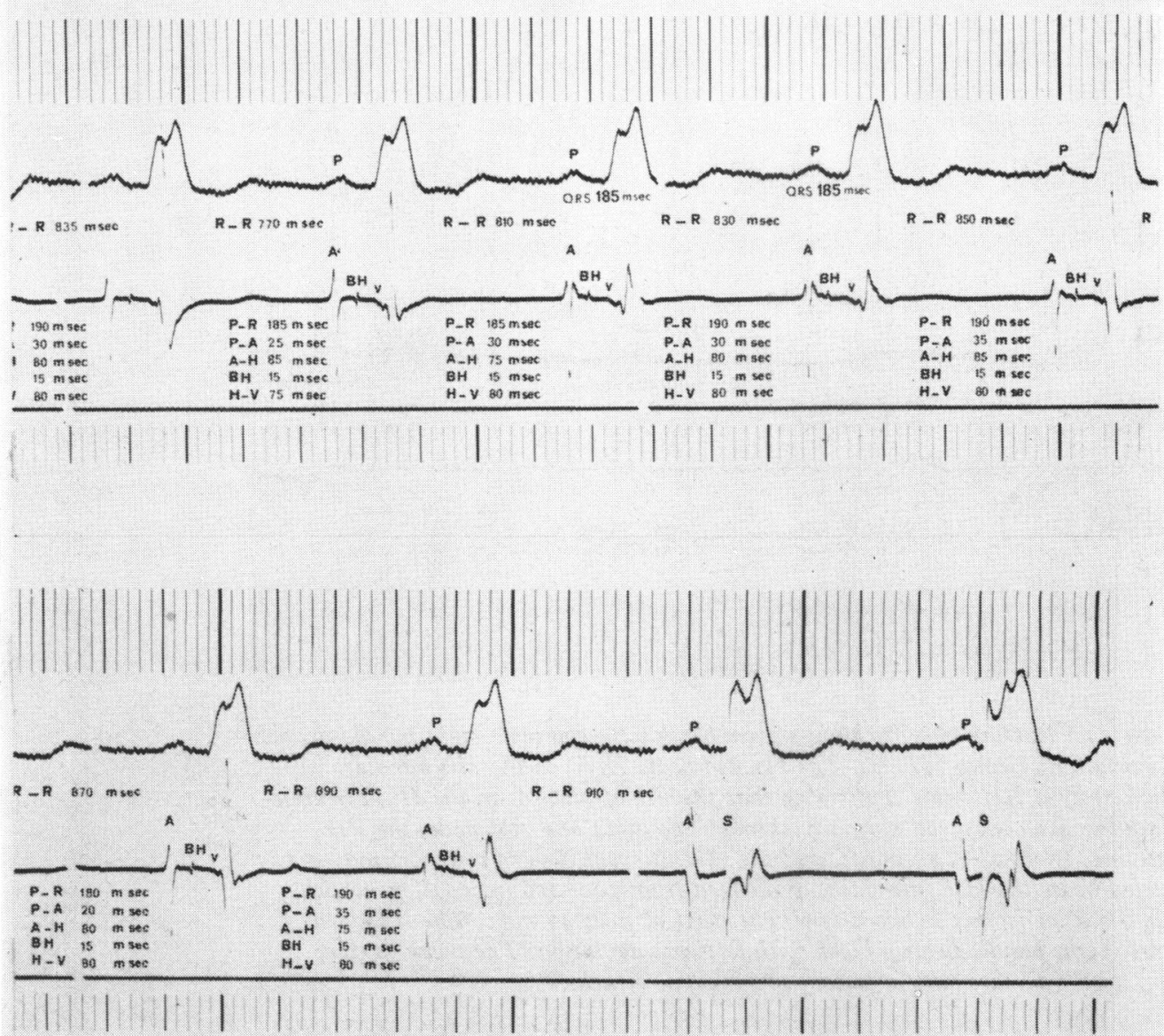

FI G. 7 (Table, Case I6.) Partial His-Purkinje-system block (Mobitz II) with complete left bundle-branch block (Group III, B). Tracings recorded with a pacemaker in situ (Cordis standby pacemaker). Records are from a woman aged 62 years with a history of syncopal attacks. The $P R$ interval of conducted beats is normal, $180-190 \mathrm{msec}$. The HV interval is prolonged to $80 \mathrm{msec}$ (normal, 35-45 msec), indicating delayed conduction in His-Purkinje-system. Intra-atrial and AV nodal conduction are normal. Distance between two light vertical lines $40 \mathrm{msec}$. The standard leads show complete left bundle-branch block. The last two beats $(S)$ of the second strip represent paced beats. Impaired conduction was exclusively limited to His-Purkinje-system. 


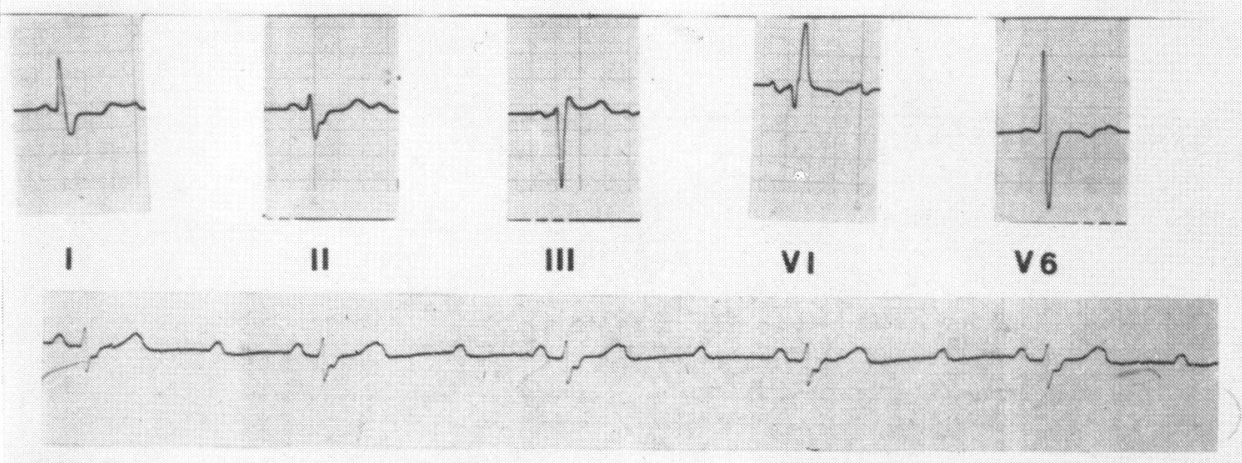

LE A D II

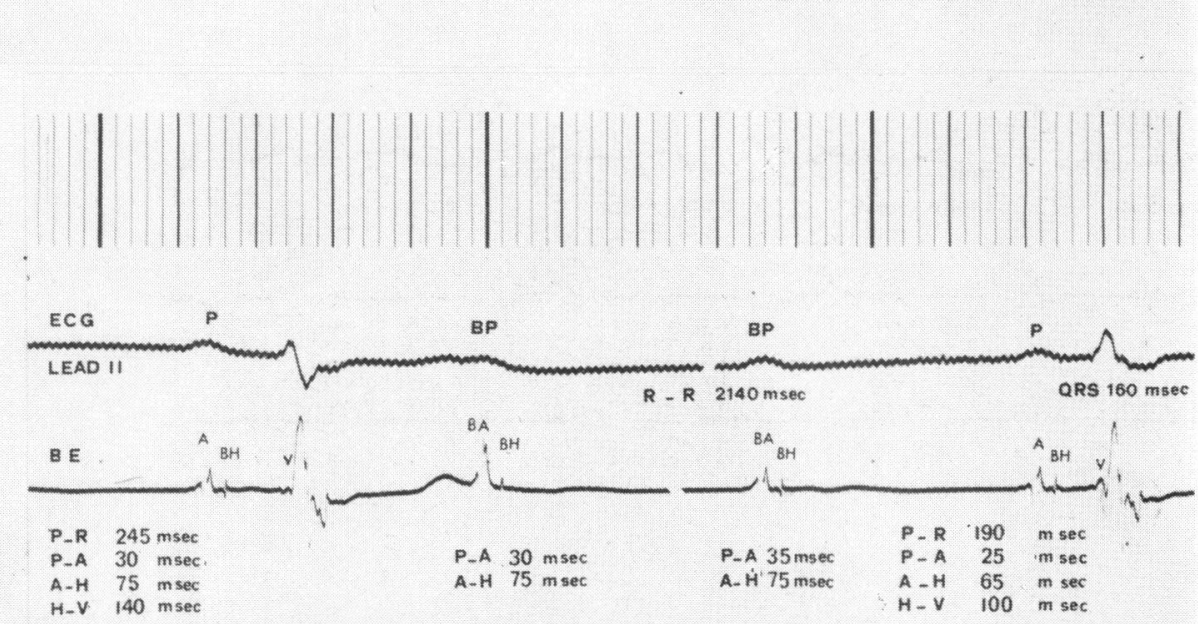

FIG. 8 (Table, Case 17.) Partial-His-Purkinje-system block with complete right bundle-branch block and left axis deviation (Group III, B). The blocked beats $(B A)$ in the His bundle electrogram are followed by a $B H$ wave confirming that the site of block is in the His-Purkinjesystem. All sinus impulses are conducted normally through the atria and $A V$ node, the $P A$ interval being 20-30 msec (normal $\leq 45 \mathrm{msec}$ ), and the $A H$ interval, 65-75 msec (normal $\leq 125$ msec). In the conducted beats the $H V$ interval is prolonged from $100-210$ msec (Wenckebach His-Purkinje-system block). Distance between two light vertical lines 40 msec. The standard tracings show complete right bundle-branch block with left axis deviation. The tracings were recorded from a man aged 63 years with a history of syncopal attacks.

AH interval, then the HV interval would require to exceed $125 \mathrm{msec}$ to cause prolongation of the PR interval to more than 200 msec in conventional surface tracings ( $P R=$ $\mathbf{P A}+\mathbf{A H}+\mathrm{HV}$ ). It follows, therefore, that when the HV interval exceeds the upper normal value of $45 \mathrm{msec}$ but measures less than $125 \mathrm{msec}$, first-degree His-Purkinje-system block may often be concealed within the normal PR interval of the scalar electrocardiogram, depending upon the normal range of variation of the $\mathrm{PA}$ and $\mathrm{AH}$ intervals at the time the tracing is recorded. Similarly, firstdegree His-Purkinje-system block may also be concealed in atrial fibrillation. In the Table, therefore, the cases have been subdivided into those with a normal PR interval, Ar (Cases 8-14), and those with a prolonged PR interval, A2 (Case 15).

An example of first-degree His-Purkinjesystem block with normal PR interval and left anterior hemiblock (Type Ar), Fig. 5 (Table, Case 9) was recorded from a man aged 50 


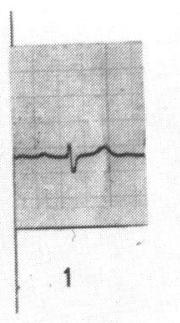

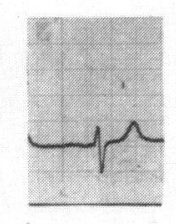

11

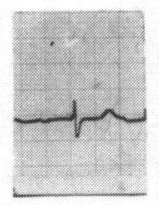

111

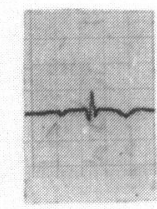

V1

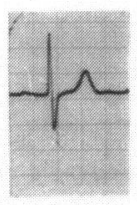

V6
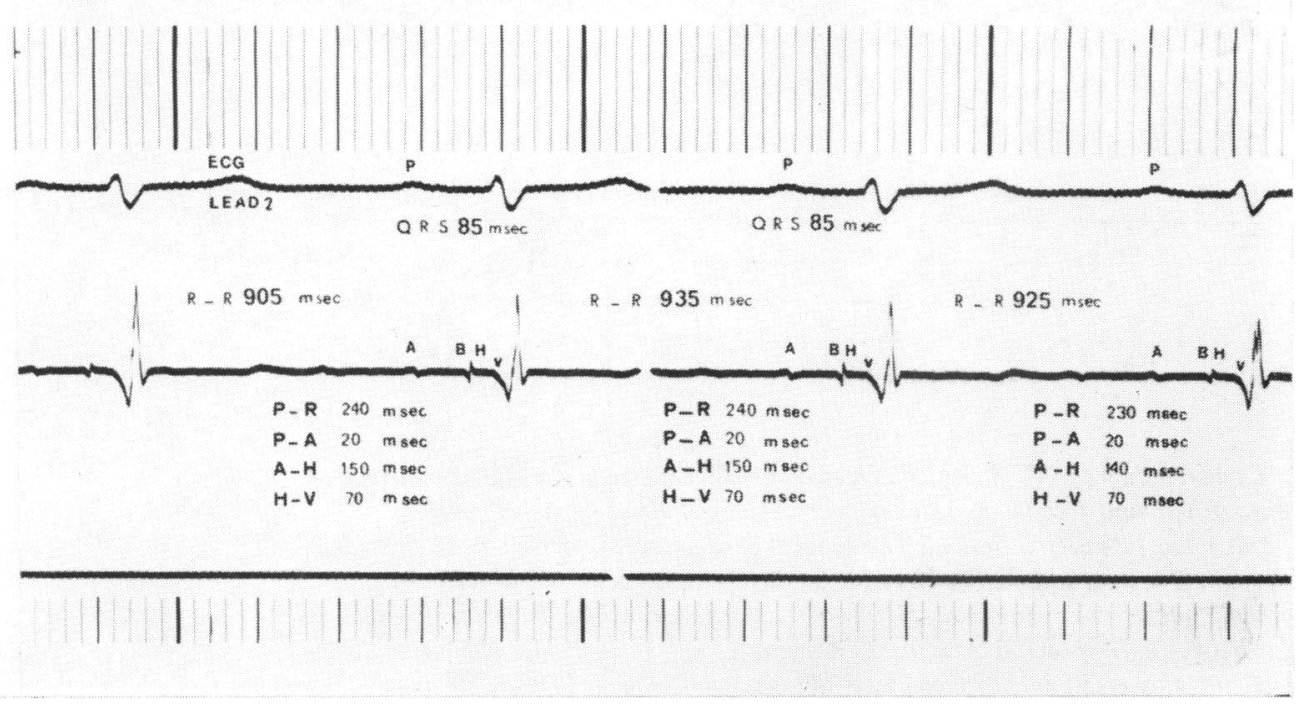

FIG. 9 (Table, Case 19.) First-degree combined AV nodal and His-Purkinje-system block (Group IV). The PR interval is prolonged, 230-240 msec. Intra-atrial conduction time is normal, $P A$ interval, $20 \mathrm{msec}$ (normal, $\leq 45 \mathrm{msec}$ ). Delayed conduction is present in the $A V$ node and His-Purkinje-system, AH interval I 40-1 $50 \mathrm{msec}$ (normal $\leq 125 \mathrm{msec}$ ), and $H V$ interval, $70 \mathrm{msec}$ (normal, 35-45 msec). Distance between two light vertical lines $40 \mathrm{msec}$. The standard leads showed $S_{1} S_{2} S_{3}$ syndrome and first-degree $A V$ block. The tracings were recorded from a man aged 19 years with rheumatic mitral and aortic valve disease.

years with congestive cardiomyopathy. The standard electrocardiogram showed a PR interval measuring $170 \mathrm{msec}$ with a normal QRS interval of $70 \mathrm{msec}$ and left anterior hemiblock (QRS axis $\left.-75^{\circ}\right)$. The His bundle electrogram showed His-Purkinje-system block with prolongation of the HV interval to $70 \mathrm{msec}$. The PA and AH intervals were normal, measuring 30 and $70 \mathrm{msec}$, respectively. The His bundle electrogram therefore revealed His-Purkinje-system block which was concealed within the normal PR interval of the surface tracing. In association with left anterior hemiblock this indicates involvement of the specialized conducting tissues, presumably by the pathological process of the cardiomyopathy.
An example of first-degree His-Purkinjesystem block with prolonged PR interval and left bundle-branch block (Type A2), Fig. 6 (Table, Case 15) was recorded from a man aged 52 years with coronary artery disease. The standard electrocardiogram showed prolongation of the PR interval to $220 \mathrm{msec}$ and complete left bundle-branch block (QRS interval $170 \mathrm{msec}$ ). The His bundle electrogram showed prolongation of the $\mathrm{HV}$ interval to 85 msec. The PA and AH intervals were normal. In conjunction with left bundle-branch block the HV interval delay is suggestive of bilateral bundle-branch block.

(B) His-Purkinje-system block with blocked impulses (Table, Cases 16-17) The criteria for 


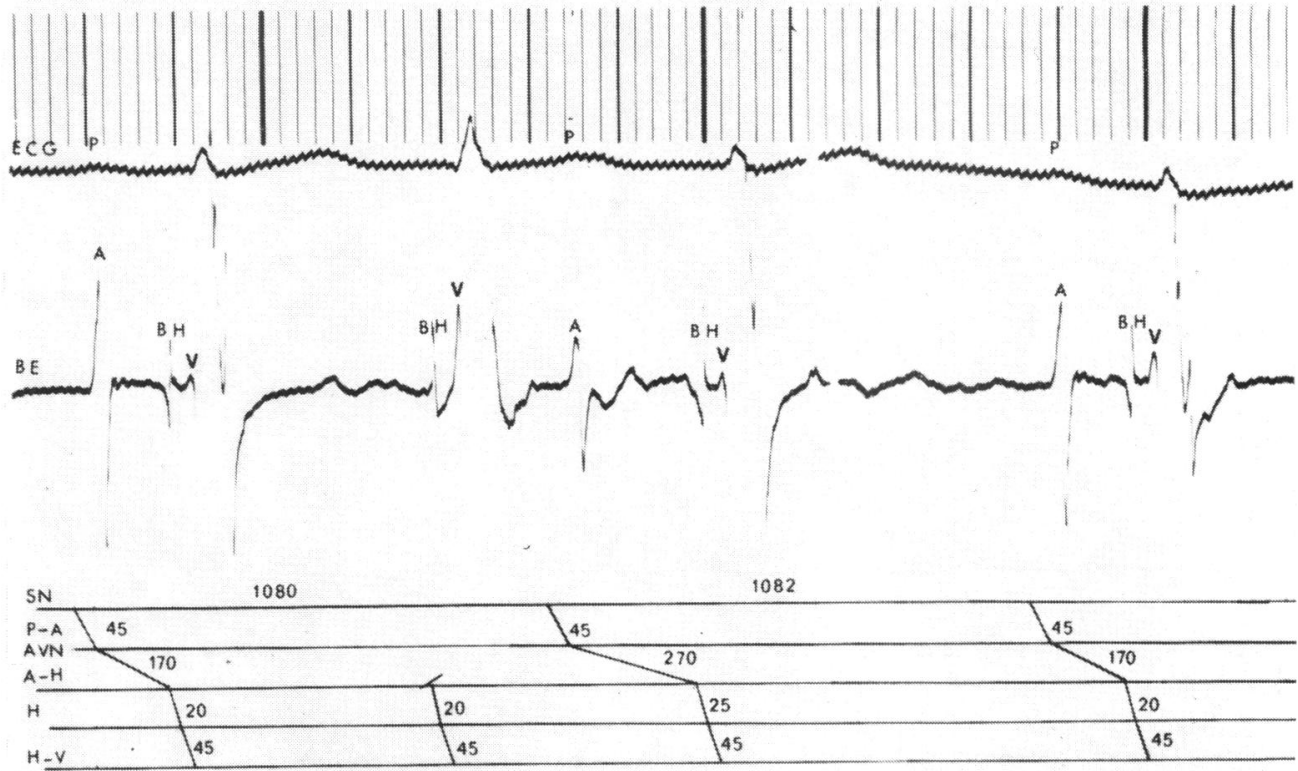

FI . IO (Table, Case 2.) First-degree AV nodal block (Group $I I, A$ ) with concealed conduction in the $A V$ node. The first, third, and fourth complexes are conducted sinus beats. The $P R$ interval is prolonged to $260 \mathrm{msec}$ in beats $I$ and 4. The second beat is an abnormal beat preceded by a $B H$ wave but not by an $A$ wave, indicating that its focus of origin is in the junctional tissues. His-Purkinje-system conduction is normal, HV interval, 45 msec. The first-degree block is entirely due to $A V$ nodal delay, $A H$ interval 170 msec (normal $\leq 125 \mathrm{msec}$ ). The $A H$ interval in beat 3 is more prolonged to 270 msec due to concealed delayed conduction in the AV node after penetration by the preceding junctional impulse. Distance between two light vertical lines 40 msec.

conducted beats are the same as for Group III (A). Blocked sinus impulses penetrate the $A V$ node, and the $A$ wave in the His bundle electrogram is followed by a $\mathrm{BH}$ wave but not by a $\mathrm{V}$ wave, i.e. the site of block is in the His-Purkinje-system. When the block is partial and the PR interval is normal, the standard electrocardiogram may correspond to Mobitz II block.

An example of His-Purkinje-system block with blocked sinus impulses and normal PR interval of the conducted beats, Fig. 7 (Table, Case 16), was recorded from a woman aged 62 years with a history of Adams-Stokes attacks over a period of four years. The standard electrocardiogram showed various degrees of AV block with blocked beats and left bundle-branch block (QRS interval 185 $\mathrm{msec}$ ). The His bundle electrogram was recorded after a permanent inhibited demand pacemaker was in situ (Cordis 'Stanicor' blocking standby pacemaker). The HV inter$\mathrm{val}$ of the sinus beats was prolonged to 80 $\mathrm{msec}$, indicating that the disturbed conduction was in the His-Purkinje-system. The PA and $\mathrm{AH}$ intervals were normal, as was the His bundle duration. When pacemaker beats occurred no $\mathrm{BH}$ wave was recorded. The association of syncope with conspicuous prolongation of the HV interval and left bundlebranch block suggests that bilateral bundlebranch block is the mechanism involved.

An example of His-Purkinje-system block with blocked sinus impulses, 2:I and 3:I His-Purkinje-system block, Fig. 8 (Table, Case 17), was recorded from a man aged 63 years with syncopal attacks over a period of two months. The electrocardiogram showed right bundle-branch block (QRS interval 160 msec), left anterior hemiblock (QRS axis $-55^{\circ}$ ), and 2:I and 3:I AV block. The PR interval of the conducted beats ranged between 190 and $315 \mathrm{msec}$. Thus, the left posterior division of the main bundle of $\mathrm{His}$ was the only pathway by which the sinus impulses could have reached the ventricles. The His bundle electrogram showed prolongation of the $\mathrm{HV}$ interval of the conducted beats (range 


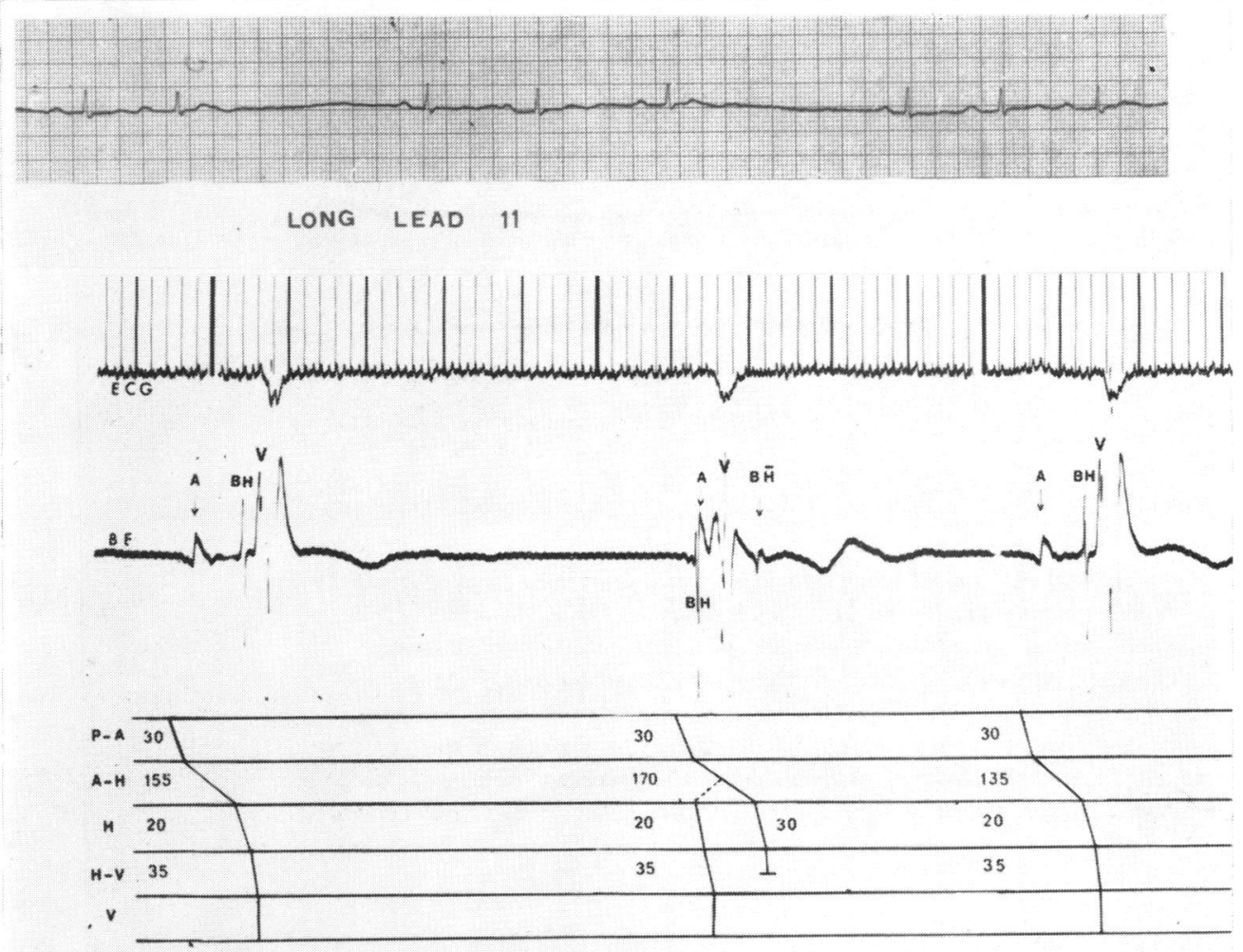

FIG. II (Table, Case 3.) First-degree AH type AV block with concealed conduction disturbance in the AV node and His-Purkinje-system (Group II, A). Long tracings showed sinus arrhythmia with prolonged PR intervals of varying duration. The delayed conduction is due to prolonged $A H$ intervals, $155 \mathrm{msec}$ in first beat and $135 \mathrm{msec}$ in third beat. The second beat is a fusion beat due to synchronization of the sinus impulse with a junctional beat. The junctional impulse activates the ventricles normally but results in increased delay of the sinus impulse in the $A V$ node so that the AH interval is prolonged to $170 \mathrm{msec}$ and complete block of the sinus impulse in the HisPurkinje-system (BH wave). Distance between two light vertical lines $40 \mathrm{msec}$.

190-210 msec), even when the PR interval was normal, i.e. Wenckebach His-Purkinjesystem block was present. The PA, AH, and $\mathrm{BH}$ intervals were normal throughout, indicating that conduction within the atria and in the proximal part of the junctional tissues was intact. When the sinus impulses were blocked, the $\mathrm{BH}$ deflections were not followed by $\mathrm{V}$ waves, confirming that the His-Purkinje-system was the site of complete block. In association with right bundle-branch block and left anterior hemiblock, this indicates that trifascicular block was the mechanism underlying the syncopal attacks.

Group IV: Multiple site AV block (Table, Cases 18-24) When the conducting system is diseased, impaired conduction may occur in the AV node and the His-Purkinje-system in combination. Group IV therefore includes cases of AV block with various types of AV nodal and His-Purkinje-system block which can only be revealed by the His bundle electrogram. All patients had some form of intraventricular conduction disturbance, left bundle-branch block was present in 3 , right bundle-branch block in 2, and 2 had $S_{1} S_{2} S_{3}$ syndrome.

A tracing was recorded of multiple site block with first-degree AV nodal and HisPurkinje-system block, Fig. 9 (Table, Case 19), from a man aged 19 years with rheumatic aortic and mitral valvular incompetence. In addition, there was calcification of the aortic valve. The standard electrocardiogram showed a prolonged PR interval $(230 \mathrm{msec})$ and the $S_{1} S_{2} S_{3}$ syndrome. The His bundle electrogram showed that the first-degree heart block 


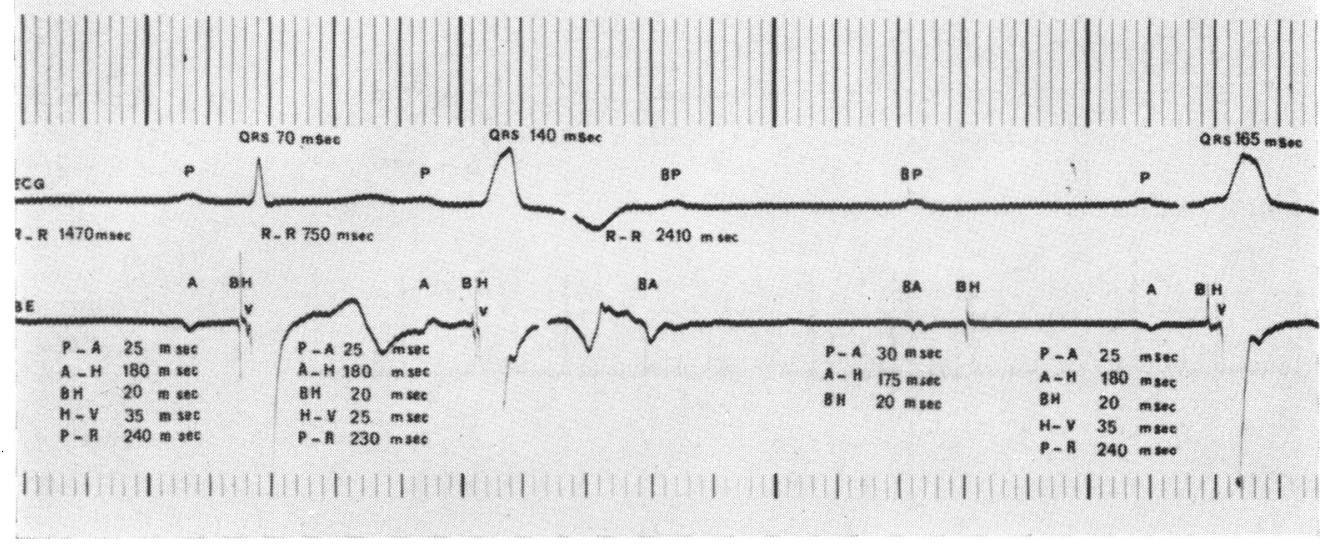

FIG. I2 (Table, Case 7.) Combined AV nodal block and His-Purkinje-system block (Group IV). The first and second beats represent conducted sinus beats with delay in the $A V$ node, $A H$ interval prolonged to $180 \mathrm{msec}$ (normal $\leq 125 \mathrm{msec}$ ). The second ventricular complex shows complete left bundle-branch block. The second blocked $P$ wave is followed by a $B H$ wave, confirming that the impulse has penetrated the AV node and is blocked in the His-Purkinjesystem. The third ventricular complex shows a complete left bundle-branch block in spite of long preceding ventricular cycle length, due to effects of penetration of the preceding sinus beat deep into His-Purkinje-system (phase 4 depolarization, see text). Distance between two light vertical lines 40 msec.

was due to a combination of first-degree $\mathrm{AV}$ nodal block (AH interval $150 \mathrm{msec}$ ) and firstdegree His-Purkinje-system block (HV interval $70 \mathrm{msec}$ ). Since the aortic valve was calcified, involvement of the conducting pathways by the calcific process may explain the abnormal conduction in the AV node and HisPurkinje-system.

\section{Results: Concealed conduction disturb- ances}

Concealed conduction was first described by Scherf and Shookoff (1925). Since then it has been more widely recognized and its mechanisms better defined (Langendorf, I948; Langendorf and Pick, 1956; Hoffman, Cranefield, and Stuckey, 196I). The His bundle electrogram may reveal conduction disturbances both anterograde and retrograde in the atrioventricular and His-Purkinje-systems, which are concealed on conventional surface tracings. Among the tracings of the 24 patients in this study we found 4 examples of concealed conduction revealed by the His bundle electrogram. Two patients were classified in Group II A (Cases 2 and 3) and one in Group II B (Case 7). The fourth patient was classed in Group IV (Case I8).

First-degree AV nodal block with concealed conduction in the AV node (Fig. ro, Table, Case 2) The tracing was recor- ded from a man aged 52 years. The His bundle electrogram confirmed that the prolonged PR interval (250-265 msec) of the surface electrocardiogram was entirely due to prolongation of the $\mathrm{AH}$ interval (170-180 $\mathrm{msec}$ ). The HV and QRS intervals were normal. Thus, first-degree AV nodal block was present. When abnormal beats occurred they were preceded by $\mathrm{BH}$ waves indicating that their site of origin was in the junctional tissues. The velocity of conduction of the abnormal beats to the ventricles was the same as the sinus beats (HV interval $45 \mathrm{msec}$ ), but their ventricular complexes were aberrant due to incomplete recovery of the Purkinje myocardial fibres. The AH intervals of the immediately following sinus beats occurred in time, but with a greatly prolonged AH interval (270 $\mathrm{msec}$ ). The explanation appears to be that the abnormal impulse was conducted in a retrograde direction from its site of origin and penetrated deeply into the AV node, but was blocked within it and failed to reach the atria. Consequently, the sinus rhythm was not disturbed, but increased delay in AV nodal conduction of sinus impulses immediately following the abnormal beats occurred. Thus, prolongation of the PR interval after the abnormal beats was due to concealed delayed conduction in the AV node which was shown by the His bundle electrogram. 


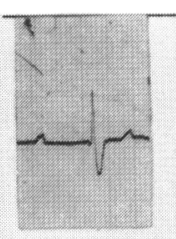

1

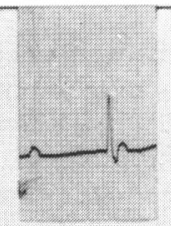

11

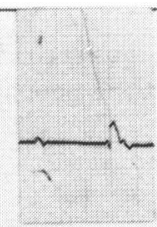

111

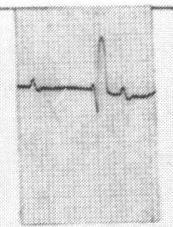

V 1

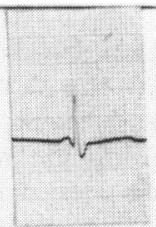

V6

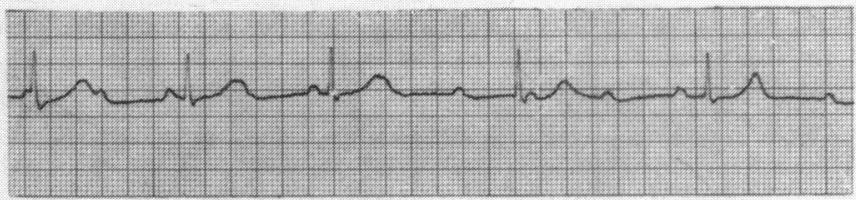

LONG LEAD 11

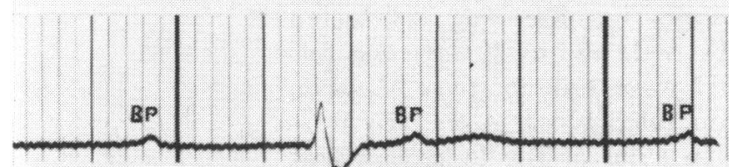

P.P. $650 \mathrm{msec}$

P.P $650 \mathrm{~m} \mathrm{sec}$

P.P $650 \mathrm{~m} \mathrm{sec}$

R - R $1675 \mathrm{msec}$

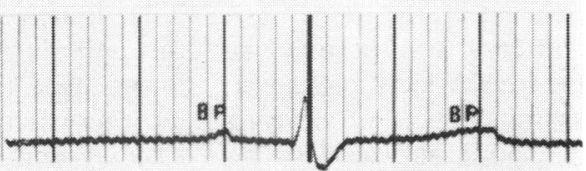

R _ R $1645 \mathrm{~m} \mathrm{sec}$

BA BH VI

P-A $10 \mathrm{msec}$

A.H $175 \mathrm{~m} \mathrm{sec}$

BH 45 insec

P.P $630 \mathrm{msec}$, P - P $650 \mathrm{msec}$

QRS 120 msex

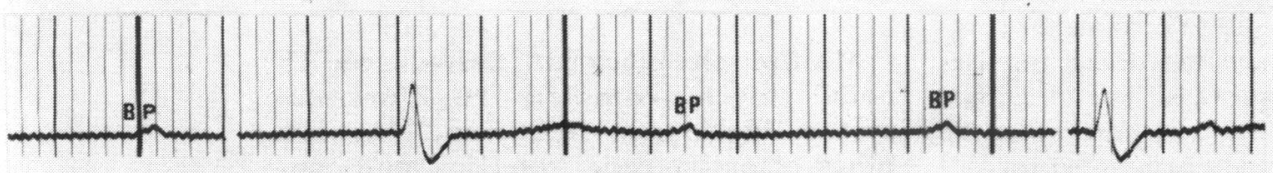

P.P $650 \mathrm{~m} \mathrm{sec}$

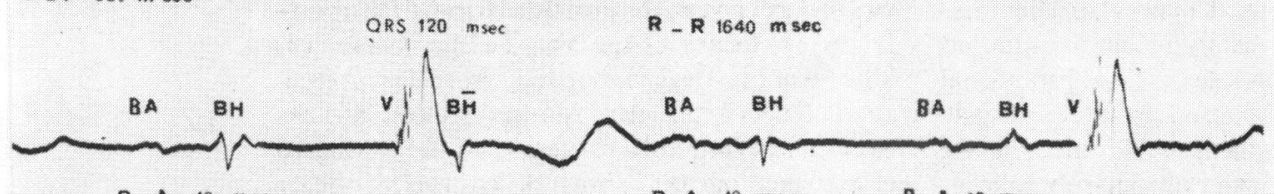

F - A $10 \mathrm{msec}$

\begin{tabular}{|c|c|c|c|}
\hline$R \quad A$ & $10 \mathrm{msec}$ & $P=A$ & 10 msec \\
\hline$A-H$ & $180 \mathrm{~m} \mathrm{sec}$ & $A-H$ & $180 \mathrm{r}$ \\
\hline BH & $45 \mathrm{msec}$ & $\mathrm{BH}$ & $65 \mathrm{misec}$ \\
\hline
\end{tabular}

A $-H \quad 180 \mathrm{msec}$

$\mathrm{BH} \quad 65 \mathrm{msec}$

$\begin{array}{ll}\text { A }-H & 180 \mathrm{msec} \\ \text { BH } & 45 \mathrm{msec}\end{array}$

A. $\mathrm{H} 180 \mathrm{msec}$

BH $45 \mathrm{msec}$

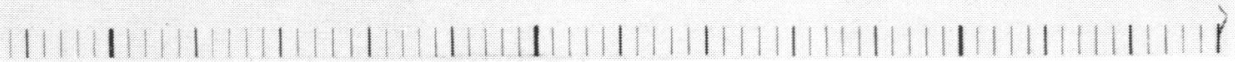

FIG. I3 (Table, Case I8.) Combined first-degree AV nodal block with complete orthograde His-Purkinje-system block and intact retrograde conduction (Group IV). The standard tracing shows complete $A V$ block, atrial rate 100 a minute, ventricular rate, 37 a minute. The His bundle electrogram (continuous strips) confirms that sinus impulses are conducted through the $A V$ node and blocked in the His-Purkinje-system. The AH interval is prolonged to 175-180 msec (normal $\leq 125 \mathrm{msec}$ ), i.e. first-degree atrioventricular nodal block (Group II). The third ventricular complex occurs late in atrial diastole and is followed by a $B \bar{H}$ wave, indicating facilitation of retrograde conduction at the site of the block. The prolonged $B H$ wave, 45 msec, indicates delayed conduction in the main bundle of His. Distance between two light vertical lines 40 msec. 
First-degree AV nodal block with concealed conduction in the AV node and His-Purkinje-system block, Fig. II (Table, Case 3) The tracing was recorded from a woman aged 64 years with coronary artery disease and syncopal attacks over a period of seven years. The standard electrocardiogram showed sinus arrhythmia with varying duration of the $P R$ interval. Long cycle lengths were terminated by junctional escape beats which frequently synchronized with sinus impulses, giving rise to fusion beats. The QRS interval was normal (80 $\mathrm{msec}$ ). The His bundle electrogram indicated that the varying PR interval of the conducted sinus beats was entirely due to varying duration of the AH intervals within the range 135I55 msec. The HV interval was normal ( 35 msec). Thus, first-degree AV nodal block was present and the varying degrees of delayed conduction in the AV node appeared to be related to varying vagal tone associated with sinus arrhythmia. When escape beats occurred they were preceded by BH waves, confirming that their site of origin was in the junctional tissues, and they were conducted to the ventricles with the same HV intervals as the sinus impulses. A rapid deflection was recorded after the $\mathrm{V}$ wave of each junctional beat but distinct from it, and though it differed in shape from the $\mathrm{BH}$ wave of sinus beats it can reasonably be assumed that it represents depolarization of some part of the His-Purkinjesystem (B $\bar{H}$ wave). On this basis, the following explanation is offered to account for competition of the sinus and junctional impulses for the conduction pathways. The junctional impulse occurred at a critical time when the sinus impulse had already penetrated the AV node but had not gained access to the HisPurkinje-system. It was therefore conducted normally to the ventricles. The junctional impulse was also conducted in a retrograde direction and penetrated the AV node causing delayed conduction of the immediately following sinus impulse so that its $\mathrm{AH}$ interval was prolonged to $170 \mathrm{msec}$, i.e. concealed conduction in the AV node has been revealed. Nevertheless, the delayed sinus impulse passed through the AV node and was blocked in the His-Purkinje-system, so that concealed His-Purkinje-system block was also revealed. The shape and duration of the $B \bar{H}$ wave suggest delayed conduction in the main bundle of His with complete block in its distal part or in both bundle-branches.

AV nodal block with blocked impulses and concealed conduction in the HisPurkinje-system (Fig. 12, Table, Case 7)
The tracing was recorded from a woman aged 80 years with syncopal attacks over a period of two years. The electrocardiogram showed varying degrees of $\mathrm{AV}$ block and prolongation of the PR interval of conducted sinus beats up to $225 \mathrm{msec}$. The His bundle electrogram was recorded during phases of varying $2: I$ AV block (Fig. 4) and 3:2 AV block. When higher degrees of AV block occurred concealed conduction disturbances were revealed in the His-Purkinje-system, and also in the Purkinje-myocardial fibres (the gate), as well as increased delay in the AV node. The AH interval was prolonged to $180 \mathrm{msec}$. Conduction in the proximal part of the His-Purkinjesystem was normal (HV interval $35 \mathrm{msec}$ ). The fourth sinus impulse was conducted through the AV node and its A wave was followed by a $\mathrm{BH}$ wave but not by a $\mathrm{V}$ wave, i.e. there is concealed block in the His-Purkinje-system. In spite of the long ventricular cycle length (24IO $\mathrm{msec}$ ) the ventricular complex of the fifth sinus impulse showed conspicuous intraventricular block (QRS I80 $\mathrm{msec})$. The explanation appears to be that the preceding blocked sinus impulse penetrated deeply into the His-Purkinje-system, with phase four depolarization of the Purkinjemyocardial fibres accounting for the intraventricular block. The His bundle electrogram showed therefore AV nodal block and Purkinje-myocardial system block, due to either manifest or concealed conduction of sinus impulses.

Multiple site block with first-degree AV nodal block, complete His-Purkinjesystem block, and right bundle-branch block of orthograde impulses, and concealed retrograde conduction of idioventricular beats (Fig. 13, Table, Case 18) The tracing was recorded from a woman aged 67 years with Adams-Stokes attacks over a period of 5 years. The standard electrocardiogram showed complete heart block, atrial rate I00 a minute, ventricular rate 37 a minute. The ventricular complexes measured $120 \mathrm{msec}$ and resembled right bundle-branch block, suggesting that the idioventricular focus was located in the contralateral left ventricle. The His bundle electrogram showed that each sinus $P$ wave was followed by an abnormal BH wave measuring up to $65 \mathrm{msec}$ in duration, and the $\mathrm{BH}$ waves were not followed by $\mathrm{V}$ waves so that the site of complete block was the His-Purkinje-system. The AH interval was also abnormally prolonged (180 msec). Thus the sinus impulses were delayed in the AV node and probably also in the main bundle of His, but were 
completely blocked in the His-Purkinje-system. However, when idioventricular impulses occurred late in atrial diastole they were followed by an abnormal deflection ( $\mathrm{B} \overline{\mathrm{H}}$ wave) which is distinct from the $\mathrm{V}$ wave of the idioventricular beat. The explanation appears to be that the $B \bar{H}$ wave represents depolarization of the main bundle of His in a retrograde direction by the idioventricular impulse. That this is the likely mechanism is supported by the premature occurrence of the $B \bar{H}$ wave. Thus, concealed retrograde conduction has been revealed by the His bundle electrogram. This observation has important physiological implications for it supports the concept that facilitation of retrograde conduction in complete orthograde $\mathrm{AV}$ block is independent of retrograde atrial activation (Cohn and Fraser, 1914; Scherf and Schott, 1953; Fletcher and Morton, 1968). The explanation may be that the preceding sinus impulse induces electrophysiological changes at the site of complete block in the His-Purkinje-system, which facilitate the passage of the retrograde idioventricular impulse when this occurs at a critical stage in atrial diastole.

\section{Discussion}

All the patients in this study had organic heart disease. Necropsy studies of the specialized conduction fibres in patients dying of heart block have confirmed the importance of localized changes in the fibres of the AV node and His-Purkinje-system (Lev, 196I; Zoob and Smith, 1963; Lenegre, I964; Rosenbaum et al., 1968; Davies and Harris, 1969). The proximal tissues of the conducting system are closely related to the fibrous skeleton of the ventricles and may be involved in its degenerative processes, for example by spread of the calcific process in diseased mitral and aortic valves as in Case 18. The His-Purkinje-system may be involved by ischaemic processes as in Case 22, or the infiltrative processes of a cardiomyopathy as in Case 9. Chronic heart block however may develop without any apparent cause, and the explanation may be in the nature of the highly specialized conduction fibres. Nothing is known about their rate of growth with increasing age, but it seems likely that if cardiac enlargement develops it may outpace the capacity of the Purkinje fibres to adapt to the increased muscle mass leading to stretching rupture and fibrous replacement with resultant impaired conduction. Thus the His bundle electrogram reveals more precisely the quality and quantity of AV block than is possible with conventional surface tracings. Some questions pertaining to its use will now be discussed.
The outstanding complication of heart block is recurrent Adams-Stokes attacks and these are regarded as an indication for artificial pacing either temporary or permanent. However, Adams-Stokes attacks rarely occur in the presence of the examiner and the description of a witness to the attack alone may be available. Moreover, if the period of cardiac arrest is less than 5 seconds, unconsciousness may not supervene and the electrocardiogram may not show blocked beats during several recordings. The His bundle electrogram may show a localized block in the His-Purkinjesystem, even if the PR and QRS intervals are normal, as in Case 9, i.e. it may reveal a latent intraventricular block. In addition, AdamsStokes attacks may occur in patients with atrioventricular nodal block (Group II) as in Cases 2-7, all of whom had had at least one previous Adams-Stokes attack, and in Group III His-Purkinje-system block (Cases 8-I7). Nothing is known about any difference in prognosis between these two sites of block so far as sudden death is concerned, but the His bundle electrogram will differentiate them and this may have therapeutic implications. Intra-atrial internodal block and atrioventricular nodal block (Groups I and II) are likely to respond to sympathomimetic drugs, whereas His-Purkinje-system block is unlikely to be affected by such drugs, and immediate pacing may be the treatment of choice. Lastly, it is significant that in Groups III and IV where His-Purkinje-system block was present, standard electrocardiograms showed intraventricular block, suggesting that a disease process affecting a bundlebranch may spread proximally to involve the main bundle or the contralateral bundle resulting in bilateral bundle-branch block. Thus, the occurrence of intraventricular block in a patient with a history of syncope probably indicates extensive involvement of the Purkinje fibres, even if the PR interval is normal. Finally, apart from its potential clinical value in assessment of heart block the His bundle electrogram can reveal electrophysiological changes such as concealed conduction, as in Cases 2, 3, 7, and 18, which add to the basic understanding of impulse conduction and impulse formation in the human heart.

\section{References}

Alanís, J., González, H., and López, E. (I958). Electrical activity of the bundle of His. Fournal of Physiology, 142, 127.

Alanís, J., López, E., Mandoki, J. J., and Pilar, C. (I959). Propagation of impulses through the atrioventricular node. American fournal of Physiology, I97, II7I. 
Bekheit, S., Murtagh, J. G., Morton, P., and Fletcher, E. (I97I). Measurements of sinus impulse conduction from electrogram of bundle of His. British Heart Fournal, 33, 719.

Castillo, C. A., and Castellanos, A. (1970). His bundle recordings in patients with reciprocating tachycardias and Wolf-Parkinson-White syndrome. Circulation, 42, 271.

Cohn, A. E., and Fraser, F. R. (1914). The occurrence of auricular contractions in a case of incomplete and complete heart block due to stimuli received from the contracting ventricles. Heart, 5 , I4I.

Damato, A. N., Lau, S. H., Helfant, R., Stein, E., Patton, R. D., Scherlag, B. J., and Berkowitz, W. D. (1969). A study of heart block in man using His bundle recordings. Circulation, 39, 297.

Damato, A. N., Lau, S. H., Bobb, G. A., and Wit, A. L. (I970). Recording of A-V nodal activity in the intact dog heart. American Heart fournal, 80, 353.

Davies, M., and Harris, A. (1969). Pathological basis of primary heart block. British Heart fournal, 3I, 219.

Fletcher, E., and Morton, P. (1968). Atrioventricular dissociation with intact retrograde conduction. British Heart fournal, 30, 458.

Hoffman, B. F., Cranefield, P. F., and Stuckey, J. H. (196I). Concealed conduction. Circulation Research, 9, 194.

Hoffman, B. F., Moore, E. N., Stuckey, J. H., and Cranefield, P. F. (1963). Functional properties of the atrioventricular conduction system. Circulation Research, 13, 308.

James, T. N. (1963). The connecting pathways between the sinus node and A-V node and between the right and the left atrium in the human heart. American Heart fournal, 66, 498.

Langendorf, R. (I948). Concealed A-V conduction: the effect of blocked impulses on the formation and conduction of subsequent impulses. American Heart fournal, 35, 542.

Langendorf, R., and Pick, A. (1956). Concealed conduction. Further evaluation of a fundamental aspect of prolongation of the cardiac impulse. Circulation, 13, 38r.

Lenegre, J. (1964). Etiology and pathology of bilateral bundle branch block in relation to complete heart block. Progress in Cardiovascular Diseases, 6, 409.

Lev, M. (I96I). Complete left bundle branch block: a physiologic-pathologic correlation. Report of a case. American Heart fournal, 61, 149.

Mobitz, W. (1924). Uber die unvollständigestorüng der Erregungsuberleitung zwischen Vorhof und Kammer des menschlicken Herzens. Zeitschrift für die gesamte experimentelle Medizin, 41, I80.

Narula, O. S., Cohen, L. S., Samet, P., Lister, J. W.,
Scherlag, B. J., and Hildner, F. J. (1970a). Localisation of $\mathrm{A}-\mathrm{V}$ conduction defects in man by recording of the His bundle electrogram. American fournal of Cardiology, 25, 228.

Narula, O. S., and Samet, P. (1970). Wenckebach and Mobitz type II A-V block due to block within the His bundle and bundle branches. Circulation, 4I, 947.

Narula, O. S., Scherlag, B. J., Javier, R. P., Hildner, F. J., and Samet, P. (I970b). Analysis of the A-V conduction defect in complete heart block utilising His bundle electrograms. Circulation, 41, 437.

Narula, O. S., Scherlag, B. J., and Samet, P. (I970c). Pervenous pacing of the specialized conducting system in man. Circulation, 41, 77.

Narula, O. S., Scherlag, B. J., Samet, P., and Javier, R. P. (1971). Atrioventricular block. Localization and classification by $\mathrm{His}$ bundle recordings. American fournal of Medicine, 50, 146.

Rosenbaum, M. B., Elizari, M. V., and Lazzari, J. O. (1968). Los Hemibloqueos. Ed. Paidos, Buenos Aires.

Rosenbaum, M. B., Elizari, M. V., and Lazzari, J. O. (1970). The hemiblocks; new concepts of intraventricular conduction based on human anatomical, physiological and clinical studies. Oldsmar, Florida, Tampa Tracings.

Scherf, D., and Cohen, J. (1964). The Atrioventricular Node and Selected Cardiac Arrhythmias. Grune and Stratton, New York.

Scherf, D., and Schott, A. (1953). Extrasystoles and Allied Arrhythmias. Heinemann, London.

Scherf, D., and Shookhoff, C. (I925). Reizleitungsstorungen im Bündel. I. Wiener Archiv für innere Medizin und deren Grenzgebiete, 10, 97.

Scherlag, B. J., Lau, S. H., Helfant, R. H., Berkowitz, W. D., Stein, E., and Damato, A. N. (1969). Catheter technique for the recording of His bundle activity in man. Circulation, 39, 13.

Schuilenburg, R. M., and Durrer, D. (1970). Observations on atrioventricular conduction in patients with bilateral bundle-branch block. Circulation, 4r, 967.

Wenckebach, K. F. (1899). Zur Analyse des urregelmässigen Pulses. Zeitschrift für klinische Medizin, 37,475 .

Wenckebach, K. F. (1906). Beiträge Zur Kenntnis der menschlichen Hertztätigkeit. Archiv für Anatomie und Physiologie, 297.

Zoob, M., and Smith, K. S. (1963). The aetiology of complete heart-block. British Medical fournal, 2, II49.

Requests for reprints to Dr. E. Fletcher, Cardiovascular Unit, Belfast City Hospital, Lisburn Road, Belfast BT9 $7 \mathrm{AB}$, Northern Ireland. 